\title{
URGENSI ETIKA DEMOKRASI DI ERA GLOBAL: MEMBANGUN ETIKA DALAM MENGEMUKAKAN PENDAPAT BAGI MASYARAKAT AKADEMIS MELALUI PENDIDIKAN KEWARGANEGARAAN
}

\author{
Nufikha UlfaH, Yayuk Hidayah, \& Meiwatizal Trihastuti \\ Institut Teknologi Sumatera, Universitas Ahmad Dahlan, \& STKIP Pasundan Cimahi \\ Yayuk.hidayah@pgsd.uad.ac.id
}

\begin{abstract}
Abstrak
Istilah demokrasi secara singkat didefinisikan sebagai pemerintahan atau kekuasaan dari rakyat, oleh rakyat, dan untuk rakyat. Jika ditinjau dari sudut organisasi, negara demokrasi adalah negara yang diselenggarakan berdasarkan kehendak dan kemauan rakyat, negara demokrasi yaitu negara kedaulatan rakyat. Sedangkan etika memiliki arti: ilmu yang membahas tentang apa yang biasa dilakukan atau ilmu tentang adat kebiasaan; etika dapat juga dijelaskan sebagai "ilmu pengetahuan yang membahas tentang asas-asas akhlak (moral). Adapun visi dari Pendidikan Kewarganegaraan itu sendiri yaitu agar menjadi warga negara yang baik yang memiliki civic knowledge, civic dispositions, serta mempu mengartikulasi civic skills (berkaitan dengan kecakapan intelektual: mengidentifikasi, menggambarkan, menjelaskan, menganalisis, menilai, dan mengambil serta mempertahankan posisi atas suatu isu; dan kecakapan partisipatif: berinteraksi, memantau, dan memengaruhi) dalam kehidupan masyarakat, bangsa, dan negara yang demokratis. Pendidikan Kewarganegaraan diharapkan dapat melahirkan warga negara demokratis yang memiliki kecerdasan, kritis, bertanggung jawab serta partisipatif dalam menghadapi perubahan sabagai akibat dan tantangan globalisasi.
\end{abstract}

Kata kunci: Etika Demokrasi, Demokrasi Pancasila, Pendidikan Kewarganegaraan

\section{abstract}

The term democracy is briefly defined as the government or power of the people, by the people, and for the people. When viewed from the point of view of the organization, a democratic state is a country organized based on the will and will of the people, a democratic state that is a country of people's sovereignty. While ethics has a meaning: science that discusses what is commonly done or the science of customs; ethics can also be described as "the science of moral principles." The vision of Citizenship Education itself is to be a good citizen who has civic knowledge, civic dispositions, and articulate civic skills (relating to intellectual proficiency: identifying, describing, describing, analyzing, assessing, and taking and maintaining positions on an issue; and participatory skills: interacting, monitoring, and influencing) in the lives of democratic societies, nations, and countries. Citizenship Education is expected to give birth to democratic citizens who have intelligence, critical, responsible and participatory in the face of changes such as the consequences and challenges of globalization.

Keywords: Democratic Ethics, Pancasila Democracy, Citizenship Education

\section{PENDAHULUAN}

Manusia dan HAM adalah dua kata yang sulit untuk dipisahkan. Sejak kelahirannya di bumi manusia lahir dengan membawa hak-hak kodrat yang melekat integral dalam hidupnya. Pada dasarnya manusia adalah makhluk bebas. Kemerdekaan dalam menyatakan pendapat merupakan bagian dari hak asasi manusia. Kebebasan merupakan tuntutan manusia sebagai makhluk individu. Di sisi lain manusia adalah makhluk sosial. Manusia tidak dapat hidup sendiri, dia selalu hidup di tengah-tengah sosialitasnya, baik itu kelompok kecil masyarakat, suku, bangsa atau negara. Dalam kedudukan manusia sebagai makhluk sosial inilah masalah HAM menjadi sangat kompleks. Banyak benturan manusia yang satu dengan manusia yang lain, kelompok yang satu dengan kelompok yang lain. Hak dan kebebasan secara alamiah dimiliki setiap 
manusia. Dalam hidup berkelompok hak ini diambil atau didelegasikan kepada kelompoknya untuk pengaturan hidup bersama.

Setiap negara wajib melindungi hak asasi manusia setiap warga negaranya. Di Inonesia HAM manusia diatur dalam UUD 1945 Pasal 27-34, termasuk hak atas kebebasan dalam berserikat, berkumpul dan dalam mengeluarkan pendapat (Pasal 28E (3). Berkaitan dengan kebebasan mengeluarkan pendapat, juga diatur dalam UU No. 9 Tahun 1998 yang merupakan ketentuan yang bersifat regulatif. Pasal 1 ayat (1) dijelaskan bahwa: "Kemerdekaan menyampaikan pendapat adalah hak setiap warga negara untuk menyampaikan pikiran dengan lisan. tulisan. dan sebagainya secara bebas dan bertanggung jawab sesuai dengan ketentuan peraturan perundangundangan yang berlaku."

Kemudian dijelaskan pula mengenai asas dan tujuan dalam mengemukakan pendapat dalam pasal 3 ayat (1), (2), (3), dan (4) dan pasal 4 a, b, c, dan d yaitu kemerdekaan menyampaikan pendapat di muka umum dilaksanakan berlandaskan asas keseimbangan antara hak dan kewajiban; musyawarah dan mufakat; kepastian hukum dan keadilan; professional dan manfaat; serta bertujuan mewujudkan kebebasan yang bertanggung jawab sebagai salah satu pelaksanaan HAM sesuai dengan Pancasila dan UUD 1945; perlindungan hokum dalam menjamin kebebasan menyampaikan pendapat; mewujudkan berkembangnya iklim yang kondusif bagi berkembangnya partisipasi dan kreativitas warga negara sebagai perwujudan hak dan tanggung jawab dalam kehidupan berdemokrasi; dan mampu menempatkan tanggung jawab sosial dalam kehidupan bermasyarakat, berbangsa, dan bernegara, tanpa mengabaikan kepentingan perorangan atau kelompok. Berdasarkan penjelasan mengenai kebebasan menyampaikan pendapat tersebut sejalan dengan Pasal 19 Deklarasi Universal HAM yang berbunyi: "Setiap orang berhak atas kebebasan mempunyai dan mengeluarkan pendapat, dalam hak ini termasuk kebebasan mempunyai pendapat dengan tidak mendapat gangguan dan untuk mencari, menerima, dan menyampaikan keterangan dan pendapat dengan cara apapun juga dan dengan memandang batas-batas."

Dengan demikian, maka kemerdekaan pendapat di muka umum harus dilaksanakan dengan penuh tanggung jawab, sejalan dengan ketentuan peraturan perundang-undangan yang berlaku. Bertanggung jawab berarti dapat menjawab, bila ditanyai tentang perbuatan-perbuatan yang dilakukan. Tanggung jawab berarti bahwa orang tidak boleh mengelak, bila diminta penjelasan tentang perbuatannya. Kepada siapa jawaban itu diberikan? Kepada dirinya sendiri, kepada masyarakat luas dan bahkan kalau orang beragama kepada Tuhan. (Bertens, 1993: 135). Pelaksanaan demokrasi masa kini sarat dengan demonstrasi atau unjuk rasa. Demonstrasi atau unjuk rasa merupakan wujud dari adanya kebebasan dalam menyampaikan pendapat. Kebebasan menyampaikan merupakan implementasi dari nilai-nilai HAM. Seperti yang ditulis oleh James W. Nickel dalam Bukunya yang berjudul Making Sense of Human Rights sebagaimana dikutip I Gede Pasek Eka Wisanjaya (2013), menyatakan bahwa "ketika hak asasi manusia diimplementasikan didalam hukum internasional, kita masih menyebutnya sebagai hak asasi manusia; namun manakala itu diimplementasikan didalam hokum domestik, kita condong menggambarkannya sebagai hak sipil atau hak konstitusional." Dengan demikian, sebagaimana telah dijelaskan sebelumnya, dalam konteks hukum nasional Indonesia hak konstitusional warga negara tentang 
hak kemerdekaan menyampaikan pendapat diatur secara jelas dalam Konstitusi RI yaitu UUD 1945 Pasal 28, Pasal 28E Ayat (2) dan Ayat (3).

Kebebasan berpendapat menjadi landasan utama demokrasi modern. Namun, kerap kali untuk kebebasan berpendapat itu membentur peraturan atau norma (konstitusional) yang ada sehingga mengakibatkan pelanggaran etika. Faktanya saat ini banyak sekali yang menunjukkan bahwa ternyata kebebasan mengemukakan pendapat yang tidak dilandasi rasa tanggung jawab, adanya kebebasan dalam mengemukakan pendapat saat ini menimbulkan dampak yang tidak baik disebabkan oleh penyalahgunaan "hak" tersebut yang pada akhirnya dapat merugikan orang lain.

Dikutip dari listverse.com pada Kamis (11/5/2017), berikut 7 kasus yang mengancam kebebasan berpendapat, yaitu (1) Perang Komentar di Dunia Maya; (2) Serangan pada Anonimitas;

Peningkatan Kasus Penistaan, seperti Kasus dugaan penistaan agama yang paling hangat adalah yang dialami mantan Gubernur DKI Jakarta Basuki Tjahaja Purnama; (4) Perang Melawan Jurnalisme; (5) Pemaksaan Budaya; (6) Pembunuhan untuk Pembungkaman; dan (7) Protes Sebagai Senjata.

Selain itu, kaitannya dengan kemajuan teknologi informasi komunikasi saat ini tidak hanya memberikan dampak yang positif tetapi juga memberikan dampak yang buruk. Penyampaian akan informasi begitu cepat dimana setiap orang telah dengan mudah memproduksi informasi, dan informasi yang begitu cepat tersebut melalui beberapa media sosial seperti facebook, twitter, ataupun pesan telpon genggam seperti, whatsapp dan lain sebagainya yang tidak dapat difilter dengan baik. Dalam menyampaikan informasi yang tidak benar (hoax) dengan disertai tujuan provokatif yang mnggiring pembaca dan penerima kepada opini yang negatif. Sehingga dari opini negatif, fitnah, penyebar kebencian yang diterima dan menyerang pihak ataupun membuat orang menjadi takut, terancam dan dapat merugikan pihak yang diberitakan sehingga dapat merusak reputasi dan menimbulkan kerugian materi. CNN Indonesia menyebutkan bahwa dalam data yang dipaparkan oleh Kementerian Komunikasi dan Informatika menyebutkan ada sebanyak 800 ribu situs di Indonesia yang terindikasi sebagai penyebar berita palsu dan ujaran kebencian (hate speech) (Pratama (2016). Serta masih banyak lagi fakta lainnya yang menggambarkan bagaimana kondisi pelaksanaan demokrasi di Indonesia yang berkaitan dengan hak kemerdekaan dalam mengemukakan pendapat yang tanpa memperhatikan etika dan tanpa disertai rasa tanggung jawab.

Proses demokratisasi yang semakin mengglobal sejak memasuki abad ke 21, merupakan tantangan konseptual dan kontekstual civic education atau citizenship education (pendidikan kewarganegaraan). Menurut Huntington (1991), pada saat ini dunia, termasuk Indonesia sedang berada pada gelombang demokratisasi ketiga yang sangat spektakuler yang memunculkan isu demokratisasi yang menonjol, antara lain: hubungan timbal balik perkembangan ekonomi dengan proses demokratisasi dan bentuk pemerintahan demokratis khususnya yang berkaitan dengan kebebasan individu, stabilitas politik, dan implikasinya terhadap hubungan internasional. Didalam menjawab permasalahan tentang faktor yang melatarbelakangi tumbuh dan berkembangnya proses demokratisasi, walaupun tidak dalam konteks hubungan sebab-akibat, Huntington menyimpulkan adanya "korelasi yang tinggi Antara agama Kristen Barat dengan demokrasi", dengan argument statistik bahwa dari 68 negara yang dianggap 
demokratis sebesar $57 \%$ merupakan negara yang dominan Kristen Barat, dan hanya $12 \%$ dari 58 negara yang dominan agama lainnya merupakan negara demokratis (Udin S. Winataputra \& Dasim Budimansyah, 2012: 218). John L Esposito dan John O. Voll (2016) mengadakan studi komparatif demokrasi di Iran, Sudan, Paskistan, Aljazair, dan Mesir. Didalam bukunya "Islam and Democracy" yang diterjemahkan menjadi "Demokrasi di Negara-negara Muslim", Esposito dan Voll (1996: 11): "Kebangkitan Islam dan demokratisasi di dunia muslim berlangsung dalam konteks global yang dinamis" dimana terjadi proses 'menguatnya identitas komunal dan tuntutan terhadap partisipasi politk rakyat yang muncul dalam lingkungan dunia yang begitu kompleks ketika teknologi semakin memperkuat hubungan global, sementara, pada saat yang sama identitas local, nasional, dan budaya lokal masih sangat kuat. Berdasarkan hal tersebut, dapat diindikasikan bahwa proses demokrasi tidak seyogyanya selalu diukur dari kriteria demokrasi barat, tetapi dilihat secara kontekstual, karena demokrasi sendiri tidak berkembang dalam suatu situasi yang secara sosial-kultural vakum (Udin S. Winataputra \& Dasim Budimansyah, 2012: 219). Demokrasi ideal yang diterapkan di Indonesia yang mengacu pada nilai dan norma yang berlaku di Indonesia erta menjunjung tinggi nilai dan prinsip-prinsip demokrasi.

Perkembangan demokrasi di Indonesia dapat dikembalikan pada dinamika kehidupan negara sejak Proklamasi Kemerdekaan 17 Agustus 1945 hingga saat ini, serta praksis kehidupan bermasyarakat dan bernegara yang menjadi dampak langsung dan dampak pengiring dari berlakunya setiap konstitusi serta dampak perkembangan internasional pada setiap zamannya (Udin S. Winataputra \& Dasim Budimansyah, 2012:
220).

Berbagai wacana tentang model demokrasi yang cocok dengan kondisi masyarakat Indonesia yang ber-"Bhinneka Tunggal Ika" dengan liku-liku pengalaman historis, perkembangan ekonomi, serta interaksinya dengan kecenderungan globalisasi semakin banyak dikembangkan. Diantara berbagai wacana yang menonjol, yang memiliki keterkaitan dengan tulisan ini, diantaranya yaitu Masyarakat Madani yang Bermoral yang Dicerminkan dalam Kedaulatan Rakyat yang Menjunjung Tinggi Hukum dan HAM (Suara Pembaharuan, 21 Juni 1999); Persoalan Dilematis dalam Pembangunan Masyarakat Madani Menyangkut Ketertarikan Ilmu Pengetahuan, Moralitas, Jaminan Hukum, dan Persamaan Hak (Asy'ari, dalam Republika, 23 Februari 1999); Peran Masyarakat Akademis sebagai Bagian dari Masyarakat Madani (Abdurrahman, dalam Kompas, 29 April 1999); dan Kaitan Etika Pluralisme dan Konstitusi Masyarakat Madani yang Memungkinkan Masyarakat yang Heterogen Membangun Kehidupan Bersama yang Damai (Arifin, dalam Republika, 14 Mei 1999). Berkembangnya wacana tersebut menunjukkan bahwa komitmen terhadap upaya peningkatan kualitas berkehidupan demokrasi di Indonesia sedang mengalami tahap yang memuncak. Dengan kata lain, dapat dikatakan bahwa pada masa yang akan datang instrumentasi dan praksis kehidupan demokrasi di Indonesia akan mengalami penyempurnaan yang terus menerus sejalan dengan dinamika partisipasi seluruh warga negara sesuai dengan kedudukan dan perannya dalam masyarakat (Udin S. Winataputra \& Dasim Budimansyah, 2012: 222, 223).

Karena proses demokratisasi ini menyangkut ini menyangkut partisipasi warga negara dalam proses politik, maka penyiapan warga negara agar mampu berpartisipasi secara cerdas dan 
bertanggung jawab juga merupakan isu penting dalam proses demokratisasi saat ini. Sebagaimana diyakini bahwa ethos demokrasi sesungguhnya tidaklah diwariskan, tetapi dipelajari, dan dialami. Oleh karena itu pendidikan kewarganegaraan sebagai wahana pendidikan demokrasi dalam arti luas memegang peranan yang strategis, karena secara langsung menyentuh sasaran potensial kewarganegaraan yang demokratis untuk berbagai usia. Proses demokratisasi yang harus dikembangkan bukanlah hanya untuk berdemokrasi hari ini, tetapi lebih jauh lagi untuk berdemokrasi di hari esok (Udin S. Winataputra \& Dasim Budimansyah, 2012: 218).

Berdasarkan penjelasan di atas, dapat disimpulkan bahwa pendidikan kewarganegaraan sebagai pendidikan demokrasi memegang peranan penting dalam membangun ethos demokrasi yang dibutuhkan dalam mengahadapi situasi dan kondisi demokratisasi di era global saat ini. Selanjutnya secara teori akan dibahas secara mendalam berikut.

\section{HASIL PENELITIAN DAN PEMBAHASAN Apa Etika Demokrasi itu?}

Sebelum membahas etika demokrasi, terlebih dahulu akan dibahas mengenai konsep etika dan konsep demokrasi. Sering kita mendengar kalimat-kalimat seperti ini: "Etika dan moral perlu ditegaskan kembali", "Di televisi akhir-akhir ini banyak iklan yang kurang etis", dan sebagainya. Kemudian pada masa Orde Baru kita sering mendengar tentang "moral Pancasila" dan "etika pembangunan". Pendeknya, katakata seperti itu sering mewarnai kehidupan kita sehari-hari. Dalam kondisi seperti itu, kata-kata tersebut tidak berfungsi dalam suasana iseng dan remeh, tapi sebaliknya dalam suatu konteks yang serius bahkan prinsipil.

Secara etimologi, istilah etika berasal dari Bahasa Yunani Kuno ethos (dalam bentuk tunggal) berarti: tempat tinggal yang biasa; padang rumput, kandang habitat: kebiasaan adat; akhlak, perasaan: perasaan, sikap, cara berpikir. Sedangkan (dalam bentuk jamak) etika berarti adat kebiasaan. Dalam arti jamak inilah yang melatarbelakangi filsuf Yunani Aristoteles memakai istilah etika untuk menunjukkan filsafat moral, maka "etika" berarti ilmu tentang apa yang biasa dilakukan atau ilmu tentang adat kebiasaan. Etika dapat juga dijelaskan sebagai "ilmu pengetahuan yang membahas tentang asas-asas akhlak (moral). Kata "etika biasa dipakai dalam arti: nilai-nilai dan norma moral yang dijadikan pedoman bagi seseorang atau suatu kelompok dalam mengatur tingkah lakunya. Etika berkaitan dengan masalah nilai karena pokok pembicaraan etika yaitu "baik" dan "buruk". Etika bersifat normatif untuk mengatur perilaku manusia artinya memberi norma atas apa yang harus dilakukan dan tidak boleh dilakukan (Bertens, 1993: 4-6). Dalam kehidupan sehari-hari perlu adanya sebuah nilai dan norma yang mengatur segala perilaku bagi seseorang maupun kelompok.

Kata demokrasi berasal dari Bahasa Yunani "demos" berarti orang-orang dan "kratos" berarti kekuasaan atau wewenang. Demokrasi dapat diartikan kekuatan atau otoritas rakyat. Istilah demokrasi secara singkat didefinisikan sebagai pemerintahan atau kekuasaan dari rakyat, oleh rakyat, dan untuk rakyat. Jika ditinjau dari sudut organisasi, negara demokrasi adalah negara yang diselenggarakan berdasarkan kehendak dan kemauan rakyat, negara demokrasi yaitu negara kedaulatan rakyat. Hornby., et. al (1998) mengemukakan democracy adalah "country with principles of government in which all adult citizens share through their elected representative", demokrasi merujuk pada konsep kehidupan negara atau masyarakat dimana warga negara dewasa turut 
berpartisipasi dalam pemerintahan melalui wakilnya yang dipilih. USIS (1995) menjelaskan bahwa demokrasi sebagai suatu konsep diterima sebagai “...seperangkat gagasan dan prinsip tentang kebebasan, yang juga mencakup seperangkat praktik dan prosedur yang terbentuk melalui sejarah panjang dan berliku. Pendeknya, demokrasi adalah pelembagaan kebebasan." Karena rakyat atau "people" yang manjadi pusat demokrasi. Pabotinggi (2002) menungkapkan bahwa demokrasi disikapi sebagai pemerintahan yang memiliki paradigma "otocentricity" atau otosentrisitas yakni rakyatlah yang harus menjadi kriteria dasar demokrasi. Maka dari itu Abraham Lincoln menyatakan bahwa demokrasi merupakan "the government from the people, by the people, and for the people". (Dirjen Pembelajaran dan Kemahasiswaan, 2016: 147). Demokrasi bukan hanya merupakan suatu bentuk pemerintahan, tapi bagaimana demokrasi mampu menciptakan sebuah kesepakatan "kedamaian" antarmasyarakat yang berangkat dari kepentingan "bersama".

Berdasarkan penjelasan mengenai konsep etika dan demokrasi dapat ditarik kesimpulan bahwa dalam mewujudkan penerapan demokrasi yang ideal perlu adanya suatu nilai dan norma moral yang bersifat normatif guna mengatur perilaku dalam berpartisipasi demokrasi. Dalam hal ini, di Indonesia nilai dan norma ideal yang mengatur segala perilaku warga negaranya yaitu Pancasila yang dalam sila-silanya mengandung cita-cita negara ideal bagi kelangsungan kehidupan bermasyarakat, berbangsa, dan bernegara. Selanjutnya nilai dan norma (Demokrasi Pancasila) lebih lanjut akan diuraikan di bawah ini.

\section{Demokrasi Pancasila sebagai Cita-cita Penerapan Demokrasi Indonesia}

Negara Indonesia adalah negara
Persatuan yang sistem demokrasinya mendasarkan pada asas 'Kerakyatan yang dipimpin oleh hikmat kebijaksanaan dalam permusyawaratan/ perwakilan'. Hal ini mengandung arti bahwa suatu negara demokrasi dari bangsa multikultural, multietnis serta pluralitas dalam kehidupan agama akan bertahan kokoh manakala yang diutamakan bukan pemenuhan hak-hak individu (individual rights), atau hanya hak-hak kelompk masyarakat (collective rights), melainkan juga kewajiban untuk mengembangkan solidaritas sosial (gotong royong) dalam rangka kemaslahatan dan kebahagiaan hidup bangsa secara keseluruhan. Prinsip negara demokrasi kerakyatan adalah kesetaran hak warga negara dengan menghormati hak-hak minoritas (majority rule, majority rights) mengandaikan adanya kedaulatan rakyat berdasarkan semangat kekeluargaan. Sejalan dengan hal tersebut Moh. Hatta (1992) sebagaimana dikutip Latif (2011: 413) menjelaskan bahwa "Kedaulatan Rakyat Indonesia harus berakar dalam pergaulan hidup sendiri yang bercorak kolektivisme". Oleh karena itu esensi pokok sila 'Kerakyatan yang dipimpin oleh hikmat kebijaksanaan dalam permusyawaratan perwakilan bukanlah demokrasi yang individualistik. (Kaelan, 2013:359, 360). Berdasarkan pendapat di atas, negara Indonesia adalah negara dengan multi etnis, agama, serta bangsa. Negara Indonesia merupakan negara demokrasi yang mendasarkan pada asas 'Kerayatan yang dipimpin oleh hikmat kebijaksanaan dalam permusyawaratan/perwakilan' (sila 4) dengan menjunjung tinggi HAM sebagai prinsip demokrasi serta kewajiban mengembangkan gotong royong demi kemaslahatan rakyat itu sendiri.

Pancasila sebagai dasar filsafat negara Indonesia pada hakikatnya merupakan suatu kesatuan bagian-bagian yang bersusun majemuk tunggal. Pokok 
inti sila keempat yaitu 'kerakyatan', hakikat manusia yaitu kodrat manusia dengan hakikat struktur dan pelaksanaan negara tidak dapat dipisahkan sebagaimana kodrat manusia terkandung dalam sila kedua Pancasila dan sila ketiga 'Persatuan Indonesia' yang mendahului, menjiwai, dan mendasari sila keempat (Kaelan, 2013: 360). Pada sila keempat yang unsur intinya 'kerakyatan' terkandung penjelmaan sifat hakikat kodrat manusia yaitu sebagai makhluk individu dan makhluk sosial atau disebut 'monodualis'. Oleh karena itu negara kita adalah negara 'monodualis' atau negara kerakyatan, maka demokrasi kita bersifat 'monodualis'. Hal ini mengandung konsekuensi bahwa dalam praktek pelaksanaan demokrasi, kepentingan umum lebih diutamakan dibandingkan dengan kepentingan pribadi. Atas dasar inilah maka negara Indonesia adalah negara demokrasi yang bersifat kekeluargaan yang merupakan demokrasi asli Indonesia. Hal ini sejak awal dirumuskannya Pancasila sebagai dasar negara pada tanggal 15 Juni 1945 yang mana pada saat itu Ketua BPUPKI beserta anggota pada saat membahas mengenai Hukum Dasar yang tertuang dalam Pembukaan UUD 1945 menyetujui dasar 'kekeluargaan' atau 'gotong royong' atau dasar 'keadilan sosial' (Notonagoro (1975: 175) sebagaimana dikutip Kaelan, 2013: 365).

Sebagaimana telah dijelaskan sebelumnya bahwa negara Indonesia adalah negara yang berdasarkan Pancasila. Kaitannya hakikat Pancasila dengan hakikat dan sifat negara sangat ditentukan oleh hakikat sifat kodrat manusia yakni 'monodualis', yang mengandung pengertian bahwa pendukung adanya sebuah negara adalah manusia (rakyat). Oleh karena itu Indonesia yang berdasarkan asas kerohanian Pancasila ini disebut juga negara yang bersifat 'monodualis'. Berdasarkan hal tersebut, mengandung konsekuensi dalam pelaksanaan hidup bersama dari individuindividu yang dengan sendirinya memiliki kepentingan dan kebutuhan sendiri-sendiri pula, karena itu terdapat suatu kemungkinan terjadi adanya pertentanganpertentangan. Namun perlu disadari bahwa terdapat tujuan hidup bersama yaitu damai dan tenteram. Dibutuhkan prinsip kerja sama dalam memenuhi kepentingan dan kebutuhan bersama melalui sebuah organisasi yang dalam pelaksanaannya diperlukan sebuah peraturan hukum dan jaminan untuk ditaati bagi pelaksaaan praksisnya yang selanjutnya secara peristilahan ilmiah disebut negara hukum kebudayaan (Kaelan, 2013: 366,367). Terdapat

Cita-cita filosofis yang terkandung dalam Sila Keempat Pancasila, yaitu sebagai berikut: Kerakyatan, merupakan suatu cita-cita kefilsafatan bahwa negara pada hakikatnya adalah untuk seluruh rakyat. Oleh karena itu kerakyatan merupakan cita-cita filsafat dari demokrasi dimana terdapat dua macam, yaitu demokrasi politik yang berkaitan dengan penyelenggaraan negara di bidang politik dan demokrasi sosial-ekonomi yang berkaitan dengan penyelenggaraan negara atau persamaan dalam bidang sosial ekonomi untuk mewujudkan kesejahteraan bersama. (Notonagoro (1975: 132,133) sebagaimana dikutip Kaelan (2013: 374)).

Jadi menurut sila keempat yang mengandung cita-cita kefilsafatan demokrasi, demokrasi politik merupakan sarana menuju terwujudnya kesejahteraan rakyat melalui demokrasi sosial-ekonomi.

Permusyawaratan/perwakilan

berhubungan dengan pengertian demokrasi politik dimana merupakan sarana mutlak bagi tercapainya 'kerakyatan'. Hal ini berkaitan dengan adanya Kedaulatan Rakyat seperti yang tercantum dalam Pasal 1 Ayat (2) UUD 1945 yang berbunyi "Kedaulatan adalah di 
tangan rakyat, dan dilakukan menurut Undang-Undang Dasar", adalah merupakan suatu cita-cita politik atau dasar politik yang dalam pelaksanaannya terdapat landasan moralitas, yang merupakan basis norma etis dalam pelaksanaan demokrasi yakni hikmat kebijaksanaan. Hikmat kebijaksanaan, memiliki kaidah dan makna 'dipimpin oleh hikmat kebijaksanaan' yang menurut Herati (1984) harus dilakukan analisis berdasarkan pendekatan filsafat analitika Bahasa, yaitu dari analisandum (premis yang dilakukan analisis) sebagai pangkal urai dan analisands (premis yang merupakan penguraian). Demokrasi secara hermeneutis memaknai demokrasi terutama demokrasi politik tidak hanya mendasarkan pada kuantitaif matematis, melainkan pada asas moralitas kebijaksanaan yang bersumber pada nilainilai etika musyawarah untuk mencapai mufakat. Jadi makna dipimpin yaitu seseorang yang memimpin dengan dasar moral bagi sistem demokrasi di Indonesia serta demokrasi dalam pelaksanaannya dibimbing oleh moralitas wisdom (Kaelan, 2013: 375).

Demokrasi Indonesia memiliki dua dasar yang sangat kuat, yaitu: (1) Dasar filsafat negara Indonesia adalah Pancasila, dalam kaitannya dengan sila keempat; (2) Dasar politik negara, yaitu negara yang berkedaulatan rakyat, pada hakikatnya merupakan penjelmaan dari dasar filsafat negara Indonesia yang mempunyai kedudukan yang kuat dan melekat pada keberlangsungan hidup negara Indonesia sebagaimana tercantum dalam Pembukaan UUD 1945 yang berkedudukan sebagai staatfundamentalnorm (pokok kaidah negara yang fundamental), sehingga demokrasi Indonesia secara hukum tidak dapat ditiadakan. (Kaelan, 2013: 378).

Dari uraian di tersebut di atas dapat disimpulkan bahwa sila keempat yaitu 'Kerakyatan yang dipimpin oleh hikmat kebijaksanaan permusyawaratan/perwakilan' sebagai dasar filsafat negara (asas kerokhanian negara), dijelmakan dalam dasar politik negara yaitu 'negara yang berkedaulatan rakyat' yang menjadi landasan mutlak bagi demokrasi Indonesia karena sifat demokrasi Indonesia dapat dikembalikan kepada dasar filsafatnya yaitu hakikat rakyat dan akhirnya kepada hakikat manusia.

Berdasarkan pada penjelasan di atas muncullah sebuah pertanyaan "Lalu apa kaitannya etika, Pancasila, dan demokrasi? Dapat dirumuskan secara sederhana bahwa hakikat sila ke-IV Pancasila "Kerakyatan yang dipimpin oleh hikmat kebijaksanaan dalam permusyawaratan/ perwakilan", esensinya adalah demokrasi yang dilandasi oleh kebijaksanaan yang bersumber pada asas moral kemanusiaan dan ketuhanan. Oleh karena itu menurut pandangan Pancasila, demokrasi harus berlandaskan moral keagamaan yang berasal dari Tuhan. Selain itu demokrasi juga dilandasi oleh moral kemanusiaan yang adil dan beradab. Demokrasi tidak hanya otoritas rasio, akan tetapi adanya unsur keharmonisan. Karena pada hakikatnya manusia memiliki jiwa (akal, rasa, kehendak) dan raga (fisis, insting) yang juga memiliki nafsu (jasmaniah dan rohaniah). Namun manusia juga memiliki hati nurani yang merupakan sumber kebaikan manusia yang merupakan anugerah.

Jika melihat penerapan demokrasi saat ini tidak didasari moral, namun hanya mendasarkan pada rasio (positifmatematis) dan nafsu berkuasa, kekerasan, konflik, bringas, ambisi, dan menghalalkan segala cara. Pelaksanaan sistem demokrasi di Indonesia dewasa ini tidak diletakkan pada perspektif tujuan negara untuk kemakmuran dan kesejahteraan rakyat. Sehingga hal tersebut memicu respon kontra yang beragam wujudnya dari kalangan masyarakat. Berdasarkan 
penjabaran tersebut dapat digarisbawahi bahwa nilai yang terkandung dalam Sila keIV Pancasila sebagai esensi dari dari pelaksanaan demokrasi di Indonesia dan dijadikan sumber etika yang secara normative mengatur tentang apa yang seharusnya dan tidak seharusnya dilakukan terhadap pelaku demokrasi dalam kehidupan berbangsa dan bernegara. Sebagaimana pendapat Hatta bahwa model demokrasi yang dikembangkan hendakanya bukan demokrasi yang sekedar menjiplak budaya barat secara mentah-mentah, tetapi demokrasi yang cocok dengan karakter keindonesiaan yakni demokrasi kekeluargaan berlandaskan permusyawaratan.

Demokrasi sejati memerlukan warga negara yang baik. Demokrasi tidak hanya memerlukan hukum, peraturan dan lembaga yang mampu menegakkannya, melainkan juga sikap demokratis yang didukung dengan etika dalam berdemokrasi terutama dalam mengemukakan pendapat. Selain itu, dalam sebuah demokrasi perlu adanya kesediaan untuk bekerja sama dalam membangun sebuah kompromi dengan kesadaran bahwa seseorang tidak dapat mewujudkan semua yang diinginkan serta adanya kombinasi antara kesadaran individu dan kesadaran kelompok. Oleh karena itu, secara substantif untuk mendidik warga negara yang baik guna menjamin terwujudnya masyarakat demokratis di era global, pendidikan demokrasi yang terintegrasi melalui Pendidikan Kewarganegaraan mutlak diperlukan dengan tujuan mempersiapkan warga masyarakat (terutama masyarakat dalam hal ini mahasiswa) yang mampu dan bertindak dengan etika demokratis.

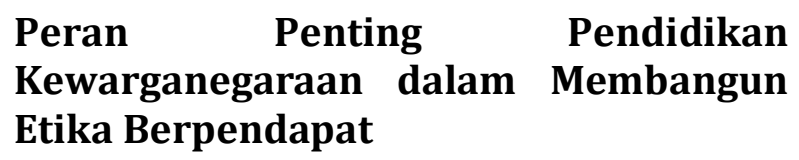

Dewasa ini sebagian masyarakat memiliki persepsi bahwa masyarakat demokratis diartikan sama dengan masyarakat bebas demontrasi, yang intinya bebas memaksakan kehendak kelompoknya dengan tekanan kekerasan. Pihak pemerintah pun cenderung terbawa arus pemikiran bahwa kebebasan merupakan akar demokrasi dikarenakan adanya suatu ketakutan terhadap sorotan dunia internasional. Sebagai konsekuensinya pemerintah yang demokratis harus memberi kebebasan penuh bagi wara negaranya untuk menyatakan pendapatnya. Kebijakan pemerintah memberikan kebebasan berpendapat kepada kelompok-kelompok dalam masyarakat ini sebenarnya merupakan musuh kebebasan yang berkedok taat pada konstitusi. Demokrasi sejati memerlukan warga negara yang baik, tidak hanya memerlukan hukum dan peraturan serta lembaga yang mampu menegakannya, melainkan juga memerlukan sikap demokratis. Oleh karena itu, secara subtantif berdimensi jangka panjang, untuk mendidik warga negara yang baik guna menjamin terwujudnya masyarakat demokratis, pendidikan demokrasi mutlak diperlukan (Zamroni, 2003: 15-17). Lickona (1991: 8) menambahkan bahwa demokrasi adalah pemerintahan oleh rakyat, maka rakyat pula yang bertanggung jawab dalam membentuk suatu kehidupan dalam konteks kebebasan bagi mereka sendiri. Hal itu berarti bahwa masyarakat seharusnya memiliki sebuah sikap yang berbudi. Pada intinya, dalam negara demokrasi yang bertanggung jawab terhadap kehidupan yang demokratis adalah masyarakat itu sendiri dalam mewujudkan suatu kebebasan perlu adanya nilai etis yang perlu dijunjung sebagai panduan moral dalam menjalankan kehidupan demokratis itu sendiri.

Pendidikan kewarganegaraan secara 
etimologis berasal dari kata "pendidikan" yang berarti usaha sadar dan terencana untuk mewujudkan suasana belajar dan proses pembelajaran agar peserta didik secara aktif mengembangkan potensi dirinya (UU No. 20 Tahun 2003 Pasal 1 Ayat (1)), sedangkan kata "kewarganegaraan" adalah segala hal ihwal yang berhubungan dengan warga negara. Cogan \& Derricot (1998: 26) menambahkan bahwa: "education should and must develop pupils potential to the full and prepare them for the world in which they live. education for citizenship embraces both responsibilities and rights in the present and preparation for citizenship in adult life...schools must lay the foundations for positive, participative citizenship in two important ways: (1) by helping pupils to acquire and understand essential information and (2) by providing them with opportunities and incentives to participate in all aspects of school life."

Berdasarkan pendapat Cogan \& Derricot, pendidikan harus dan wajib mengembangkan potensi peserta didik secara penuh dan mempersiapkan mereka untuk bias hidup di dunia dimana mereka tinggal. Pendidikan kewarganegaraan mencakup tanggung jawab dan hak di masa sekarang dan mempersiapkan warga negara dalam kehidupan yang akan datang.... Sekolah harus meletakkan fondasi untuk kewarganegaraan dan partisipasi yang positif melalui dua cara: (1) membantu peserta didik untuk memperoleh dan memahami informasi penting dan (2) memberikan mereka kesempatan dan partisipasi yang insentif di segala aspek kehidupan sekolah.

Secara yuridis, pendidikan kewarganegaraan dimaksudkan untuk membentuk peserta didik menjadi manusia yang memiliki rasa kebangsaan dan cinta tanah air. Sejalan dengan pendapat Cogan \& Derricot dalam buku Citizenship for $21^{\text {st }}$ Century: An International Perspective on
Education (1998): “...citizenship education the underliying focal point of a study, was defined as 'the contribution of education yo the development of those characteristic of a citizen'." Dari pendapat tersebut, dapat ditarik sebuah kesimpulan bahwa pendidikan kewarganegaraan sebagai fokus pembelajaran didefinisikan sebagai kontribusi pendidikan dalam mengembangkan karakter masyarakat (warga negara).

Pendidikan kewarganegaraan secara terminologis adalah program pendidikan yang berintikan demokrasi politik, diperluas dengan sumber-sumber pengetahuan lainnya yaitu pengaruh positif kolaborasi dari pendidikan sekolah, masyarakat, dan orang tua. Kesemuanya itu diproses guna melatih para peserta didik untuk berpikir kritis, analitis, bersikap dan bertindak demokratis berdasarkan Pancasila dan UUD 1945. Kemudian Direktorat Pendidikan Umum dan Kebudayaan Eropa (2005: 13) melalui bukunya yang berjudul "Citizenship Education at School in Europe" yang merupakan kumpulan hasil survey mengungkapkan mengenai gagasan 'kewarganegaraan yang bertanggung jawab' menimbulkan masalah yang berkaitan dengan kesadaran dan pengetahuan tentang hak dan kewajiban. Hal ini juga terkait erat dengan nilai-nilai kewarganegaraan seperti demokrasi dan hak asasi manusia, kesetaraan, partisipasi, kemitraan, kohesi sosial, solidaritas, toleransi keragaman dan keadilan sosial. Konsep 'kewarganegaraan yang bertanggung jawab' kini semakin meluas, terutama karena serangkaian rekomendasi dan resolusi yang relevan yang mempromosikan isu tersebut telah diadopsi oleh negara-negara anggota Dewan Eropa. Dapat disimpulkan bahwa pendidikan kewarganegaraan diharapkan mampu membentuk warga negara yang demokratis dalam bentuk partisipasi 
analitis dan krirtis yang memiliki tanggung serta menjunjung nilai-nilai kewarganegaraan guna menghadapi tantangan abad ke 21. Berdasarakan pemaparan tersebut, dapat ditarik sebuah benang merah bahwa pada hakikatnya pendidikan kewarganegaraan sebagai program pendidikan mampu mengajarkan inti daripada demokrasi politik yaitu bagaimana nilai-nilai demokrasi ditanamkan melalui proses pembelajaran guna membentuk peserta didik yang bertanggung jawab dalam menghadapi era global. Berkaitan dengan nilai, Hermann (1972) sebagaimana dikutip Udin S. Winataputra dan Dasim Budimansyah (2012: 180) secara teoritik konsep dasar pendidikan nilai sebagai esensi pendidikan kewarganegaraan, mengemukakan bahwa "...value is neither thaught nor cought, it is learned", yang artinya bahwa substansi nilai tidaklah semata-mata diajarkan dan ditangkap, tetapi lebih jauh nilai dicerna dalam arti ditangkap, diinternalisasi, dan dibakukan sebagai bagian yang melekat dalam kualitas pribadi seseorang melalui proses belajar.

Dalam konteks proses reformasi menuju Indonesia baru dengan konsepsi masyarakat madani sebagai tatanan ideal sosial-kulturalnya, maka secara paradigmatik pendidikan kewarganegaraan memiliki tiga komponen atau domain, yakni (a) sebagai kajian ilmiah pendidikan ilmu kewarganegaraan; (b) sebagai program kurikuler Pendidikan Kewarganegaraan; dan (c) sebagai gerakan sosial-kultural kewarganegaraan, yang secara koheren bertolak dari esensi dan bermuara pada upaya pengembangan pengetahuan kewarganegaraan (civic knowledge), nilai dan sikap kewarganegaraan (civic virtue/civic dispositions), dan keterampilan kewarganegaraan (civic skills) (Winataputra (2001,2006) sebagaimana dikutip Winarno (2014: 7, 8). Yang selanjutnya dijabarkan kedalam misi Pendidikan Kewarganegaraan. Adapun misi yang diemban yaitu: sosio-pedagogis yaitu mengembangkan potensi individu sebagai insan Tuhan dan makhluk sosial agar menjadi warga negara Indonesia yang cerdas, demokratis, taat hukum, beradab, dan religius; sosio-kultural yaitu memfasilitasi perwujudan cita-cita, sistem kepercayaan/nilai, konsep, prinsip, dan praksis demokrasi dalam konteks pembangunan masyarakat madani Indonesia melalui pengembangan partisipasi warga negara secara cerdas dan bertanggung jawab melalui berbagai kegiatan sosio-kultural secara kreatif yang bermuara pada tumbuh kembangnya komitmen moral dan sosial kewarganegaraan; dan substantifakademis yaitu mengembangkan struktur atau tubuh pengetahuan pendidikan kewarganegaraan, termasuk di dalamnya konsep, prinsip, dan generalisasi mengenai dan yang berkenaan dengan civic virtue atau kebajikan kewarganegaraan dan civic culture atau budaya kewarganegaraan melalui kegiatan penelitian dan pengembangan (fungsi epistemologis) dan memfasilitasi praksis sosio-pedagogis dan sosio-kultural dengan hasil penelitian dan pengembangannya itu (fungsi aksiologis) (Winarno, 2014: 12, 13).

Seperti yang telah dikemukakan sebelumnya, bahwa komponen utama pendidikan kewarganegaraan yang perlu diajarkan kepada peserta didik mencakup pengetahuan kewarganegaraan (civic knowledge), keterampilan/kecakapan kewarganegaraan (civic skills), dan sikap/watak kewarganegaraan (civic disposition) (Branson, 1999). Berdasarkan pendapat tersebut, penulis akan fokus dalam memaparkan teori mengenai keterampilan/kecakapan

kewarganegaraan (civic skill) yang berkaitan dengan judul dalam tulisan ini.

Keterampilan atau kecakapan- 
kecakapan kewarganegaraan (civic skill) merupakan komponen esensial kedua dari Civic Education (Pendidikan Kewarganegaraan). Branson (1998) menyatakan sebagai berikut. "If citizens are to exercise their rights and discharge their responsibilities as members of selfgoverning communities, they not only need to acquire a body of knowledge such as that embodied in the five organizing questions just described; they also need to acquire relevant intellectual and participatory skills". Dapat diartikan bahwa jika warga negara mempraktikkan hak-haknya dan menunaikan kewajiban-kewajibannya sebagai anggota masyarakat yang berdaulat, mereka tidak hanya perlu menguasai pengetahuan dasar, namun mereka perlu memiliki kecakapankecakapan intelektual dan partisipatoris yang relevan) (Winarno, 2014: 145).

Kecakapan-kecakapan intelektual yang penting untuk seorang warga negara yang berpengetahuan, efektif, dan bertanggung jawab, disebut sebagai kemampuan berpikir kritis yang meliputi kemampuan mengidentifikasi, menggambarkan, menjelaskan, menganalisis, menilai, mengambil, dan mempertahankan posisi atau suatu isu. Di samping mensyaratkan pengetahuan dan kemampuan intelektual, pendidkan untuk warga negara dan masyarakat demokratis harus difokuskan pada kecakapankecakapan yang dibutuhkan untuk partisipasi yang bertanggung jawab, efektif, dan ilmiah, dalam proses politik dan dalam civil society. Kecakapan partisipatif tersebut dapat dikategorikan sebagai interacting, monitoring, dan influencing (Branson (1998) sebagaimana dikutip Winarno, 2014: 146, 147). Adapun kecakapan berinteraksi (interacting) berkaitan dengan kecakapan warga negara dalam berkomunikasi (berinteraksi) dan bekerja sama dengan orang lain. Dalam hal ini, interaksi berarti bertanya, menjawab, dan berunding dengan cara yang santun. Selain itu, kemampuan berinteraksi meliputi (1) mendengarkan dengan penuh perhatian; (2) bertanya dengan efektif; (3) mengutarakan pikiran dan perasaan; dan (4) mengelola konflik melalui mediasi, kompromi, dan kesepakatan. Selanjutnya, kecakapan partisipatoris dalam hal memengaruhi (influencing) mengisyaratkan pada kemampuan warga negara untuk mempengaruhi proses politik dan pemerintahan (formal-informal) dalam masyarakat, yaitu meliputi: membuat petisi, berbicara di depan umum, bersaksi di depan badan publik, terlibat dalam kelompok advokasi, membangun aliansi, dan memberikan suara (Winarno, 2014: 148).

Adalah yang penting dan perlu dikembangkan terhadap mahasiswa sebagai akademisi yaitu memiliki keterampilan dalam mengelola pengetahuan yang menjadi tolok ukur dalam mengidentifikasi, menggambarkan, menjelaskan, menganalisis, menilai, mengambil, dan mempertahankan posisi terhadap suatu isu yang selanjutnya disebut dengan kemampuan berpikir kritis yang menjadi kemampuan dasar partisipasi, bagaimana mereka mampu berkomunikasi (berinteraksi) dan berbicara di depan umum dengan cara yang santun. Berkaitan dengan communication skills, Torney-Purta \& Vermeer (2004) memberikan contoh tentang penjabarannya yang merupakan bagian dari civic skills, yang terdiri atas cognitive and participatory civic skills.

"(1) Public speaking (present relevant information to a group clearly and effectively; clearly articulate what has been learned about a particular topic; explain how classroom and other learning contributes to the effectiveness of the project); (2) Constructive criticsm (recognize different viewpoints on an issueand understand that different 
viewpoints reflect others' interests, culture, and experience; avoid or peacefully resolve conflicts between self and others; provide valueable feedback to others); and (3)Utilization of resources (consult with others about issue related to current and future project; conduct interviews, make phone calls and write letters to obtain support from community members) (Winarno, 2014: 159).

Berdasarkan berbagai pendapat di atas, dapat disimpulkan bahwa civic skills terdiri atas 2 hal, pertama, intellectual civic skills/cognitive civic skill/civic thinking skill (keterampilan berpikir) yang meliputi aspek kognitif. Kedua, participatory skills atau civic participation skills, yaitu keterampilan interacting sebagai wujud kemampuan berpartisipasi terlibat dalam kebijakan publik.

\section{Bagaimana Pembelajaran PKn untuk mengembangkan Civic Skills di Perguruan Tinggi?}

Departemen Pendidikan Nasional (2004) dalam buku Pedoman Khusus Pengembangan Silabus dan Penilaian Mata Pelajaran Kewarganegaraan, mengemukakan bahwa garis besar mata pelajaran pendidikan kewarganegaraan mencakup pengetahuan kewarganegaraan (civic knowledge), keterampilan kewarganegaraan (civic skills), dan nilainilai kewarganegaraan (civic values). Berkaitan dengan keterampilan kewarganegaraan (civic skills) yang menjadi fokus dalam tulisan ini dan telah diuraikan sebelumnya (ditulis dalam cetak tebal), Udin S. Winataputra (2001) melalui hasil penelitiannya sebagaimana dikutip Winarno (2014: 161-163), mengidentifikasi adanya butir-butir komponen keterampilan/kecakapan kewarganegaraan. Butir-butir kecakapan kewarganegaraan yang disajikan ini dapat dipakai sebagai rujukan bagi materi mata pelajaran/mata kuliah PKn baik di tingkat sekolah maupun perguruan tinggi di Indonesia. Butir-butir tersebut sebagai berikut.

a. Kemampuan berkomunikasi secara argumentatif dalam Bahasa Indonesia yang baik dan benar atas dasar tanggung jawab sosial.

b. Kemampuan berorganisasi dalam lingkungan dengan penuh kesadaran dan tanggung jawab personal sosial.

c. Kemampuan berpartisipasi dalam lingkungan sekolah atau masyarakat secara cerdas dan penuh tanggung jawab personal dan sosial.

d. Kemampuan mengambil keputusan individual dan/atau kelompok secara cerdas dan bertanggung jawab.

e. Kemampuan melaksanakan keputusan individual dan/atau kelompok sesuai dengan konteksnya secara bertanggung jawab.

f. Kemampuan berkomunikasi secara cerdas dan etis sesuai dengan konteksnya.

g. Kemampuan memengaruhi kebijakan umum sesuai dengan norma yang berlaku dan konteks sosial-budaya lingkungan.

h. Kemampuan membangun kerja sama dengan dasar toleransi, saling pengertian, dan kepentingan bersama.

i. Kemampuan berlomba-lomba untuk berprestasi lebih baik dan lebih bermanfaat.

j. Kemampuan turut serta aktif membahas masalah sosial secara cerdas dan bertanggung jawab.

k. Kemampuan menentang berbagai bentuk pelecehan terhadap keterampilan warga negara (civic skills) dengan cara yang dapat diterima secara sosial-budaya.

l. Kemampuan turut serta aktif membahas masalah sosial secara cerdas dan bertanggung jawab.

m. Kemampuan memimpin menganalisis masalah sosial secara kritis dengan 
menggunakan aneka sumber yang ada.

n. Kemampuan memimpin kegiatan kemasyarakatan secara tanggung jawab.

o. Kemampuan memberikan dukungan yang sehat dan penuh tanggung jawab kepada calon pemimpin dalam lingkungannya.

p. Kemampuan memberikan dukungan yang sehat dan tulus terhadap pimpinan yang terpilih secara demokratis.

q. Kemampuan menunaikan berbagai kewajiban sosial sebagai anggota masyarakat dengan penuh kesadaran.

r. Kemampuan membangun saling pengertian antarsuku, agama, ras, dan golongan guna memelihara keutuhan dan semangat kekeluargaan.

s. Kemampuan berusaha membangun saling pengertian antarbangsa melalui berbagai media komunikasi yang tersedia.

t. Kemampuan berusaha untuk meningkatkan kemampuan pribadi dan kegiatan sosial budaya dengan kesadaran untuk berbuat baik.

Selanjutnya, berkaitan dengan nilainilai kewarganegaraan (civic values/civic virtue) seperti yang disebutkan sebelumnya, secara yuridis-formal, pendidikan nilai, moral, dan norma di Indonesia dilaksanakan melalui pendidikan kewarganegaraan yang berlandaskan pada Undang-Undang Dasar Negara Republik Indonesia Tahun 1945 sebagai landasan konstitusional yang pada bagian Pembukaan alinea keempat memberikan dasar pemikiran tentang tujuan negara yaitu "mencerdaskan kehidupan bangsa". Mencerdaskan kehidupan bangsa mengandung pesan terhadap pentingnya pendidikan bagi seluruh anak bangsa agar memiliki kemampuan dalam berpikir, bersikap, dan berperilaku secara cerdas baik dalam proses pemecahan masalah maupun dalam pengambilan keputusan lingkup kemasyarakatan, kebangsaan, dan kenegaraan. Hal ini sesuai dengan Tujuan Pendidikan Nasional sebagaimana tercantum dalam UU No. 20 Tahun 2003 tentang Sistem Pendidikan Nasional, yaitu "... menjadi warga negara yang demokratis serta bertanggung jawab" (Sapriya, 2012: $30)$.

Berdasarkan penjelasan di atas, dapat disimpulkan bahwa dalam pembelajaran PKn untuk mengembangkan civic skills perlu sejalan dengan pengembangan civic virtue/civic value/civic dispositions. Guna membentuk peserta didik agar menjadi warga negara yang demokratis dan bertanggung jawab, yang mampu mampu berpikir secara kritis, analitis, dan berinteraksi dalam komunikasi yang tidak mengesampikan nilai-nilai etis.

Seperti yang sudah dijelaskan sebelumnya bahwa moral erat kaitannya dengan ajaran tentang sesuatu yang baik dan buruk yang menyangkut tingkah laku dan perbuatan manusia. Dalam konteks etika, setiap orang akan memiliki perasaan apakah yang dilakukan itu benar atau salah, baik atau jelek? Pertimbangan ini dinamakan pertimbangan nilai moral (moral values). Pertimbangan nilai moral merupakan aspek yang sangat penting khususnya dalam pembentukan warga negara yang baik (be good citizen) sebagai tujuan pendidikan kewarganegaraan (Sapriya, 2012: 29. Konsepsi moralitas perlu dikaitkan dan diintegrasikan antara pemikiran moral dan tindakan bermoral serta pengalaman dalam kehidupan sosial. Pemikiran moral dapat berkembang dari tingkat yang paling rendah yang berorientasi pada kepatuhan otoritas karena takut akan hukuman fisik ke tingkat yang lebih tinggi yaitu berorientasi pada pemenuhan keinginan pribadi, loyalitas pada kelompok, pelaksanaan tugas dalam masyarakat sesuai dengan peraturan dan hukum, sampai yang paling tinggi yakni mendukung kebenaran atau nilai-nilai hakiki, khususnya mengenai kejujuran, 
keadilan, penghargaan atas HAM, dan kepedulian sosial. Tindakan moral yang selaras dengan pemikiran moral hanya mungkin dicapai melalui pencerdasan emosional dan spiritual serta pembiasaan. Demikian juga tindakan demokratis tidak akan mewarnai kehidupan suatu masyarakat, apabila kondisi yang ada tidak mendorong untuk bertindak demokratis serta bertanggung jawab (Darmiyati Zuchdi, 2009: 7).

$\begin{array}{cc}\text { Berdasarkan } & \begin{array}{c}\text { penjelasan tersebut, } \\ \text { dapat ditarik }\end{array} \text { kesimpulan bahwa }\end{array}$ pertimbangan nilai moral (moral values) yang mencakup pemikiran moral (moral thinking) dan tindakan moral (moral action) mutlak diperlukan dalam tatanan kehidupan suatu masyarakat demokratis kini, mengingat adanya kebebasan berinteraksi dan berkomunikasi (mengemukakan pendapat) sebagai wujud partisipasi politik dan pemerintah saat ini yang dinilai kebablasan, sehingga pada ahirnya memunculkan sebuah cita-cita terhadap pelaksanaan demokrasi "democracy not demo crazy".

Mengacu pada realitas demokrasi di Indonesia, yang disubordinasikan dalam Pendidikan Kewarganegaraan dengan tujuan untuk membangun kesadaran peserta didik akan hak dan kewajibannya sebagai warga negara dan mampu menggunakannya secara demokratis dan beradab yang sesuai dengan konsep demokrasi sudah saatnya dilakukan. Dalam konteks pendidikan demokrasi, John Dewey sebagaimana dikutip A. Ubaidillah (2009) menjelaskan bahwa demokrasi bukan hanya suatu bentuk pemerintahan, tetapi lebih sebagai pola hidup bersama dan hubungan dari pengalaman berkomunikasi.

\section{Pengalaman di IAIN Ponorogo}

Beberapa hal yang perlu diperhatikan dalam pembelajaran pendidikan kewarganegaraan adalah orientasi/tujuan, materi, metode, dan evaluasi pembelajaran. Berdasarkan pengalaman saya (penulis) sejak 2016-sekarang dalam mengampu mata kuliah Pendidikan Kewarganegaraan di IAIN Ponorogo lebih menekankan pada proses pembelajaran yang demokratis, ditunjukkan dengan materi-materi yang disampaikan selama proses perkuliahan dirancang dalam pembelajaran yang menekankan pada prinsip-prinsip model pembelajaran aktif (active learning) dengan evaluasi pembelajaran kolaboratif antara kuantitatif dan kualitatif.

Dalam pembelajaran pendidikan kewarganegaraan di perguruan tinggi, sebagaimana yang disusun oleh Dirjen Pembelajaran dan Kemahasiswaan Kemenristek Dikti RI (2016) terdapat dalam buku "Pendidikan Kewarganegaraan untuk Perguruan Tinggi" materinya terdiri dari:

1. Esensi Dan Urgensi Identitas Nasional Sebagai Salah Satu Determinan Pembangunan Bangsa Dan Karakter.

2. Urgensi Integrasi Nasional Sebagai Salah Satu Parameter Persatuan Dan Kesatuan Bangsa.

3. Nilai Dan Norma Konstitusional UUD NRI 1945 Dan Konstitusionalitas Ketentuan Perundang-Undangan Di Bawah UUD.

4. Harmoni Kewajiban Dan Hak Negara Dan Warga Negara Dalam Demokrasi Yang Bersumbu Pada Kedaulatan Rakyat Dan Musyawarah Mufakat.

5. Hakikat, Instrumentasi, Dan Praksis Pelaksanaan Demokrasi Di Indonesia.

6. Historis Konstitusional, Sosial-Politik, Kultural, Serta Konteks Kontemporer Penegakkan Hukum Yang Berkeadilan

7. Dinamika Historis Dan Urgensi Wawasan Nusantara Sebagai Konsepsi Dan Pandangan Kolektif Kebangsaan Indonesia Dalam Konteks Pergaulan Dunia

8. Urgensi Dan Tantangan Ketahanan Nasional Dan Bela Negara Bagi 
Indonesia Dalam Membangun Kolektif Kebangsaan.

9. Menyelenggarakan Project Citizen Untuk Mata Kuliah Pendidikan Kewarganegaraan.

10. Dampak Globalisasi dalam Kehidupan Bermasyarakat, Berbangsa, dan Bernegara.

Penulis menggunakan buku yang disusun oleh tim Dirjen Pembelajaran dan Kemahasiswaan Kemenristek Dikti RI (2016) sebagai rujukan serta mengadaptasi materi-materi yang menjadi pokok bahasan pada tiap-tiap pertemuan dalam kegiatan perkuliahan. Adapun tujuan pembelajaran mata kuliah pendidikan kewarganegaraan di perguruan tinggi pada hakikatnya sebagai upaya dalam mengembangkan kemampuan utuh calon sarjana dan profesional sebagai bagian dari masyarakat yang terdidik perlu memahami tentang Indonesia, memiliki kepribadian Indonesia, memiliki rasa kebangsaan Indonesia, dan mencintai tanah air Indonesia. Dengan demikian, ia menjadi warga negara yang baik dan terdidik (smart and good citizen) yang memiliki pengetahuan kewarganegaraan (civic knowledge), sikap kewarganegaraan (civic dispositions) dan mengartikulasikan ketrampilan kewarganegaraan (civic skills) dalam kehidupan masyarakat, bangsa, dan negara yang demokratis (Dirjen Pembelajaran dan Kemahasiswaan, 2016: 1). Kemudian, Capaian Pembelajaran Mata Kuliah yang mengacu pada Kerangka Kualifikasi Nasional Indonesia (KKNI) dapat dilihat pada tabel berikut.

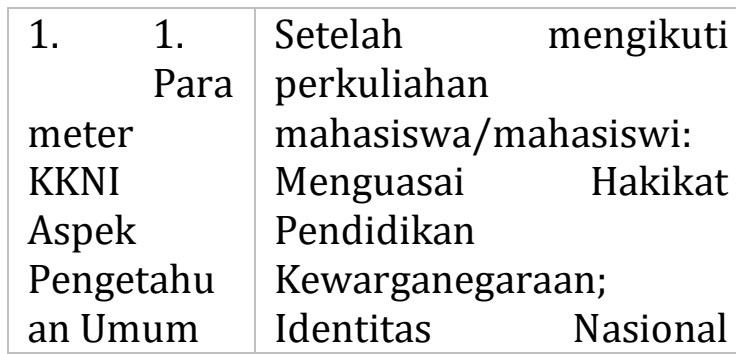

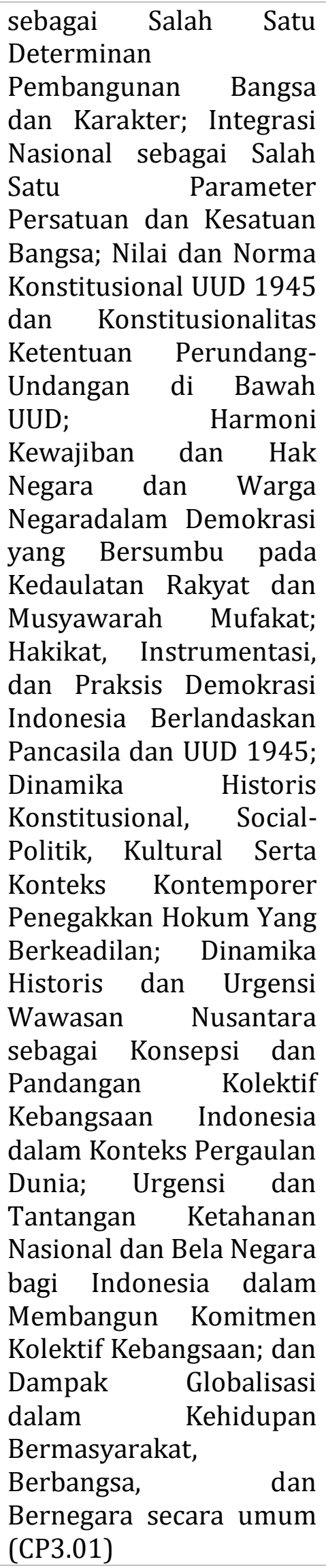

Determinan

Pembangunan Bangsa Nasional sebagai Salah Satu

\section{an} Bangsa; Nilai dan Norma Konstitusional UUD 1945

Ketentuan PerundangUndangan di Bawah UUD; Harmoni Kewajiban dan Hak Negara dan Warga Negaradalam Demokrasi yang Bersumbu pada Kedaulatan Rakyat dan Musyawarah Mufakat; Hakikat, Instrumentasi, dan Praksis Demokrasi Indonesia Berlandaskan Pancasila dan UUD 1945; Dinamika Historis Ronstitusional, SocialPolitik, Kultural Serta Konteks Kontemporer Penegakkan Hokum Yang Berkeadilan; Dinamika Historis dan Urgensi Wawasan Nusantara sebagai Konsepsi dan Pandangan Kolektif Kebangsaan Indonesia dalam Konteks Pergaulan Dunia; Urgensi dan Tantangan Ketahanan Nasional dan Bela Negara bagi Indonesia dalam Membangun Komitmen Kolektif Kebangsaan; dan Dampak Globalisasi dalam Kehidupan Bermasyarakat, Berbangsa, dan (CP3.01) 


\begin{tabular}{|c|c|}
\hline $\begin{array}{l}1 . \quad 2 . \\
\text { meter } \\
\text { KKNI } \\
\text { Aspek } \\
\text { Sikap dan } \\
\text { Tata Nilai }\end{array}$ & $\begin{array}{l}\text { 1. Menjunjung tinggi nilai } \\
\text { kemanusiaan dalam } \\
\text { menjalankan tugas } \\
\text { berdasarkan agama, } \\
\text { moral, dan etika (CP1.02) } \\
2 . \quad \text { Berkontribusi } \\
\text { dalam peningkatan } \\
\text { mutu kehidupan } \\
\text { bermasyarakat, } \\
\text { berbangsa, bernegara, } \\
\text { dan kemajuan } \\
\text { peradaban berdasarkan } \\
\text { Pancasila (CP1.03) } \\
\text { 3. Berperan sebagai } \\
\text { warga negara yang } \\
\text { bangga dan cinta tanah } \\
\text { air, memiliki } \\
\text { nasionalisme serta rasa } \\
\text { tanggungjawab pada } \\
\text { negara dan bangsa } \\
\text { (CP1.04) } \\
4 . \quad \text { Taat hukum dan } \\
\text { disiplin dalam kehidupan } \\
\text { bermasyarakat dan } \\
\text { bernegara (CP1.07) } \\
5 . \quad \text { Menginternalisasi } \\
\text { nilai, norma, dan etika } \\
\text { akademik (CP1.08) } \\
\text { 6. Menunjukkan } \\
\text { sikap bertanggungjawab } \\
\text { atas pekerjaan dibidang } \\
\text { keahliannya secara } \\
\text { mandiri (CP1.09) }\end{array}$ \\
\hline
\end{tabular}

Berdasarkan tabel capaian pembelajaran mata kuliah di atas, selanjutnya dijabarkan ke dalam tujuan pembelajaran pada materi tiap-tiap pertemuan (RPS). Pada tujuan pembelajaran setiap pertemuan disesuaikan dengan materi yang disampaikan, kolaboratif antara aspek pengetahuan dan sikap serta tata nilai. Aspek sikap serta tata nilai inilah yang djadikan dasar dalam pengembangan ranah civic skill (keterampilan kewarganegaraan) yang meliputi keterampilan intelektual (cognitive/intellectual civic skills) dan keterampilan partisipatoris (partisipatory skills).

\section{KESIMPULAN}

Demokrasi sejati memerlukan warga negara yang baik. Demokrasi tidak hanya memerlukan hukum, peraturan dan lembaga yang mampu menegakkannya, melainkan juga sikap demokratis yang didukung dengan etika dalam berdemokrasi terutama dalam mengemukakan pendapat. Selain itu, dalam sebuah demokrasi perlu adanya kesediaan untuk bekerja sama dalam membangun sebuah kompromi dengan kesadaran bahwa seseorang tidak dapat mewujudkan semua yang diinginkan serta adanya kombinasi antara kesadaran individu dan kesadaran kelompok. Demokrasi bukan hanya suatu bentuk pemerintahan, tetapi lebih sebagai pola hidup bersama dan hubungan dari pengalaman berkomunikasi. Pendidikan kewarganegaraan merupakan program kurikuler yang mempunyai kontribusi penting dalam membentuk dan mewujudkan warga negara yang cerdas seperti yang diamanatkan dalam UUD 1945, yaitu smart and good citizenship. Oleh karena itu, secara substantif untuk mendidik warga negara yang baik guna menjamin terwujudnya masyarakat demokratis di era global, pendidikan demokrasi yang terintegrasi melalui Pendidikan Kewarganegaraan mutlak diperlukan dengan tujuan mempersiapkan warga masyarakat (terutama masyarakat dalam hal ini mahasiswa) yang mampu dan bertindak dengan etika demokratis. Pendidikan Kewarganegaraan diharapkan dapat melahirkan warga negara demokratis yang memiliki kecerdasan, kritis, bertanggung jawab serta partisipatif dalam menghadapi perubahan sabagai akibat dan tantangan globalisasi. 
Melalui proses pembelajaran Pendidikan Kewarganegaraan, diharapkan para peserta didik dapat mengembangkan civic skills perlu sejalan dengan pengembangan civic virtue/civic value/civic dispositions. Adapun aspek sikap serta tata nilai inilah yang djadikan dasar dalam pengembangan ranah civic skill (keterampilan kewarganegaraan) yang meliputi keterampilan intelektual (cognitive/intellectual civic skills) dan keterampilan partisipatoris (partisipatory skills). Guna membentuk peserta didik agar menjadi warga negara yang demokratis dan bertanggung jawab, yang mampu mampu berpikir secara kritis, analitis, dan berinteraksi dalam komunikasi yang tidak mengesampikan nilai-nilai etis (nilai-nilai yang terkandung dalam Pancasila, Sila keempat).

\section{DAFTAR PUSTAKA}

Bertens, K. 1993. Etika. Jakarta: Gramedia Pustaka Utama.

Branson, Margaret S, et. al. 1999. Belajar "Civic Education" dari Amerika. Yogyakarta: LKiS.

Cogan, John J. \& Derricot, Ray. 1998. Citizenship for The 21 $1^{\text {st }}$ Century: An International Perspective on Education. London: Kogan Page.

Dirjen Pembelajaran dan Kemahasiswaan. 2016. Pendidikan Kewarganegaraan untuk Perguruan Tinggi. Jakarta: Kemenristekdikti.

European Commission (Directorate-General for Education and Culture). 2005. Citizenship Education at School in Europe (Survey). Belgium: Eurydice.

Kaelan. 2013. Negara Kebangsaan Pancasila. Yogyakarta: Paradigma

Lickona, T. 1991. Educating for Character: How Our Schools Can Teach Respect and Responsibility. Buku terjemahan Juma Abdu Wamaungo. Jakarta: Bumi Aksara.

Sapriya. 2012. Pembelajaran Pendidikan Kewarganegaraan (PKn). Jakarta: Direktorat Jenderal Pendidikan Islam, Kemenag RI.

Undang-Undang Negara Republik Indonesia Tahun 1945.

Undang-Undang No. 09 Tahun 1998 tentang Kemerdekaan Menyampaikan Pendapat di Muka Umum

Undang-Undang Nomor 20 Tahun 2003 tentang Sistem Pendidikan Nasional.

Winarno. 2014. Pembelajaran Pendidikan Kewarganegaraan: Isi, Strategi, dan Penilaian. Jakarta: Bumi Aksara.

Winataputra, Udin S. \& Budimansyah, Dasim. 2012. Pendidikan Kewarganegaraan dalam Perspektif Internasional: Konteks, Teori, dan Profil Pembelajaran. Bandung: Widya Aksara Press.

Zamroni. 2003. Pendidikan untuk Demokrasi: Tantangan Menuju Civil Society. Yogyakarta: BIGRAF Publishing.

Zuchdi, Darmiyati. 2009. Humanisasi Pendidikan: Menemukan Kembali Pendidikan yang Manusiawi. Jakarta: Bumi Aksara.

https://suud.co.id/pendidikan/pendidikan-kewarganegaraan-dan-demokrasi-indonesia/ Diakses pada tanggal 07-08-2018, pukul 15.07.

https://mti.binus.ac.id/2017/07/03/penyalahgunaan-informasiberita-hoax-di-media-sosial/ Diakses pada tanggal 10-08-2018, pukul 09.48. 